626

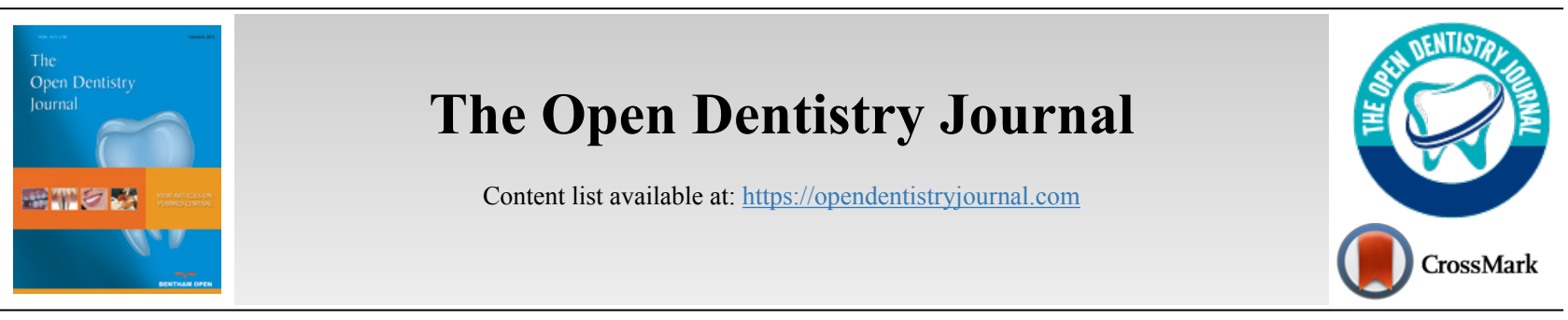

CLINICAL TRIAL STUDY

\title{
Attachment-Retained Unilateral Partial Denture versus Tooth Implant- Supported Prosthesis in Mandibular Distal Extension Cases: A Randomized Controlled Trial
}

\author{
Mohamed Sharaf ${ }^{1, *}$ and Asharaf Eskander ${ }^{2}$ \\ ${ }^{1}$ Department of Prosthetic, University of Menoufia, Al Minufiyah, Egypt \\ ${ }^{2}$ Department of Prosthetic, Cairo University, Giza, Egypt
}

\begin{abstract}
:
Objective:

To evaluate patients' satisfaction, biting force measurement, and radiographic evaluation of abutment teeth of tooth implant-supported fixed partial denture, unilateral attachment, and conventional partial denture in mandibular distal extension cases.

Materials and Methods:

Twenty-four participants were selected according to the following criteria: participants with unilateral mandibular distal extension with las standing second premolar abutment; participants having abutments with sufficient occluso-gingival height and good periodontal condition. Participants were divided into the following three equal groups: participants of the implant group received fixed tooth implant-supported fixed partial dentures, attachment group participants received unilateral attachment removable partial dentures, and conventional group participants received conventional removable partial dentures. The evaluation included patient satisfaction using "OHIP14" questionnaires, biting force
\end{abstract} measurement, and radiographic evaluation of terminal abutments using the ANOVA test.

Results:

Participants of the implant group were mainly satisfied with their prosthesis than the attachment group, which is higher than the conventional. Regarding biting force measurement, there is a statistically significant difference $(\mathrm{p}<0.05)$ between all groups, including the implant group and attachment group, as well as between attachment and conventional group $(\mathrm{p}<0.05)$. The conventional group showed statistically significant ( $<<$ 0.05 ) highest mean bone loss, while there was no statistically significant difference between implant and attachment groups; both showed statistically significantly lower mean amounts of bone loss.

\section{Conclusion:}

The tooth implant-supported fixed prosthesis could be considered a superior line of treatment for managing distal extension cases. Unilateral attachment, which is considered an excellent alternative in the case of implant placement, is not recommended.

Keywords: Biting force, Distal extension, Implants, Partial denture, Tooth implant connection, Unilateral attachment.

\begin{tabular}{|l|l|l|r} 
Article History & Received: February 20, 2021 & Revised: August 02, 2021 & Accepted: August 07, 2021
\end{tabular}

\section{INTRODUCTION}

The proportion of partially dentate patients is increasing due to the maintenance and improvement of oral health care. Nowadays, people are losing fewer teeth, resulting in an increased need to treat partial rather than complete edentulism [1 - 4]. Many patients require replacing missing teeth and asso-

\footnotetext{
* Address correspondence to this author at the Department of Prosthetic, University of Menoufia, Al Minufiyah, Egypt; Tel: 01223095900;

E-mail: dent_1983@yahoo.com
}

ciated structures to enhance appearance, improve masticatory efficiency, prevent undue over-eruption or drifting of the teeth, and improve phonetics [3 - 5]. Variable options are available in rehabilitating the partially edentulous patients as the treatment plan varies from a removable denture to fixed prosthesis supported by tooth, implants, or both and attachment retained prosthesis $[6,7]$. The most applicable line of treatment for partially edentulous patients, especially distal extension cases, is conventional partial denture. The treatment with removable partial dentures is a non-invasive and low-cost solution for the 
prosthetic rehabilitation of patients with shortened dental arches who have functional or esthetic demands for posterior teeth replacement. Nevertheless, the main drawbacks of treatment with removable partial dentures are caries, alveolar ridges resorption, loss of correct occlusion, fracture of clasps or occlusal rests, and inflammation of the underlying mucosa from traumatic irritation [8 - 10]. Another line of treatment is implanted tooth-supported prosthesis. Teeth can be connected to an osseointegrated implant as bone, prosthesis, and the implant will compensate for the micro-movements of the teeth. Therefore, implants can be connected easily to stable and rigid teeth [11 - 13]. It seems that splinting with an extra tooth may provide more effective compensation for compromised periodontal supports [14]. The fixed prostheses which have minimum abutment support have a high failure rate. The toothimplant success rate could be improved by connecting more than one natural tooth abutment $[15,16]$. Implant tooth connection provides many advantages, such as increasing the treatment options, eliciting teeth proprioception, reducing cost, providing support against load, reducing the numbers of implants for restoration, and avoiding cantilever bridge [15, 17]. Tooth implant connection problems could be overcome by using teeth of the healthy periodontium with dense bone support. Tooth and implant should be connected rigidly and parallel to each other, short-span bridges permanent cementation and equal distribution of occlusal forces should be preferred, avoiding both parafunctional habits and cantilever extensions [15]. Regarding the use of attachment, it is not an outdated treatment modality in dentistry as it provides many advantages as they reduce the bulk of removable partial dentures. It becomes better tolerated by the patient and provides better stimulation for the oral mucosa $[18,19]$; easier to repair when necessary, decreases caries susceptibility by eliminating food stagnation around the clasp [20]. Also, attachments can be used as stress directors in the distal extension area and effective direct retainers for removable partial dentures and as a connector for sectional dentures [21]. Patient satisfaction is a human experience, appraised subjectively by an individual, regarding the extent to which the care received has met certain expectations, and it is a summation of all the patient's expectations in a health care setting [22, 23]. Patient satisfaction enhances the care and the treatment outcomes by analyzing patient satisfaction and public perception [24]. The quality of prostheses assessed by clinicians does not always coincide with the patients' subjective judgment. Although several studies failed to show statistically significant relations between the two variables, other studies showed weak or moderately significant associations [25 - 27]. The quality of the prosthetic treatment may affect oral health, which is related to improving quality of life and patients' satisfaction $[26,28,29]$; therefore, one of the reliable methods for evaluating patient satisfaction is The Oral Health Impact Profile, which aims to capture impacts related to oral conditions rather than impacts that may be attributed to specific oral disorders or syndromes [30]. "The Oral Health Impact Profile -14", which is a shortened version of the OHIP-49, contains just 14 selected items, thereby making it more practical to administer in the clinical setting [31, 32]. A 14item Post-Oral Health Impact Profile scale was utilized in an effective, retrospective way so that the changing direction of numerous items were addressed after prosthetic restoration [33]. Tooth loss and decrease in the power of the masticatory muscles may lead to improper mastication, which is important for eating and nutrition. Prosthetic rehabilitation procedures should aim to restore or maintain adequate function to compensate for teeth loss [34]. Measurement of the biting force is considered a reliable method for evaluating masticatory muscles, biomechanical properties, and prosthetic treatment [35]. Evaluation by radiograph is considered an accurate method to measure alveolar crestal bone loss [36]. The purpose of this clinical trial was to compare the patients' satisfaction, biting force measurement, and alveolar bone loss around the abutment teeth between the three different designs. The research hypothesis was that the implant group would provide a better result than other groups.

\section{MATERIALS AND METHODS}

Twenty-four patients were selected according to the following criteria: 1) Patients with unilateral mandibular distal extension area with the last standing tooth, the second premolar; 2) The participants having abutments with sufficient occluso-gingival height of its clinical crown with the good periodontal condition and no signs of mobility or inflammation; 3) participants with adequate inter-arch space and no tempromandibular joint disorders. All patients should have no para-functional habits, full opposing arch or an acceptable fixed restoration and minimal bone height $11 \mathrm{~mm}$ at the lower second molar area.

Panoramic and periapical radiographs were made for each patient to evaluate sufficient bone height for implant placement, the amount of bone support of the abutment, crown/root ratio, the width of periodontal ligament space, and continuity of the lamina dura. Cone beam computerized tomography was done for every patient of the implant group.

\subsection{Patient Grouping}

Patients were randomly divided (sealed envelopes technique) into three equal parallel groups; each of eight patients, where the allocation concealment key was at the chairman of the department. The study was approved by the Ethical Committee and adhered to the principles of the Declaration of Helsinki registered at clinical trials.gov (NCT04301115) (Fig. 1).

\subsection{Sample Size}

Sample size calculation was done using the comparison of OHIP-14 score between clasp and precision attachment groups. Through the search of the literature, it was found that only one publication reported the mean and standard deviation of OHIP-14 between the 2 groups in a bar chart, showing 37 males and females. We used the figure to extract the corresponding values using specified software. After performing the needed calculations, the estimated mean \pm stander deviation of OHIP-14 in the clasp group was approximately $11.86 \pm 4.7$, while in the precision attachment group, it was approximately $4.8 \pm 3.1$. Accordingly, we calculated that the minimum proper sample size was 8 participants in each group to reject the null hypothesis with 
$80 \%$ power at $\alpha=0.05$ level using Student's $t$-test for independent samples. Sample size calculation was done using
PS Power and Sample Size Calculations software, version 3.0.11 for MS Windows (William D. Dupont and Walton D., Vanderbilt University, Nashville, Tennessee, USA).

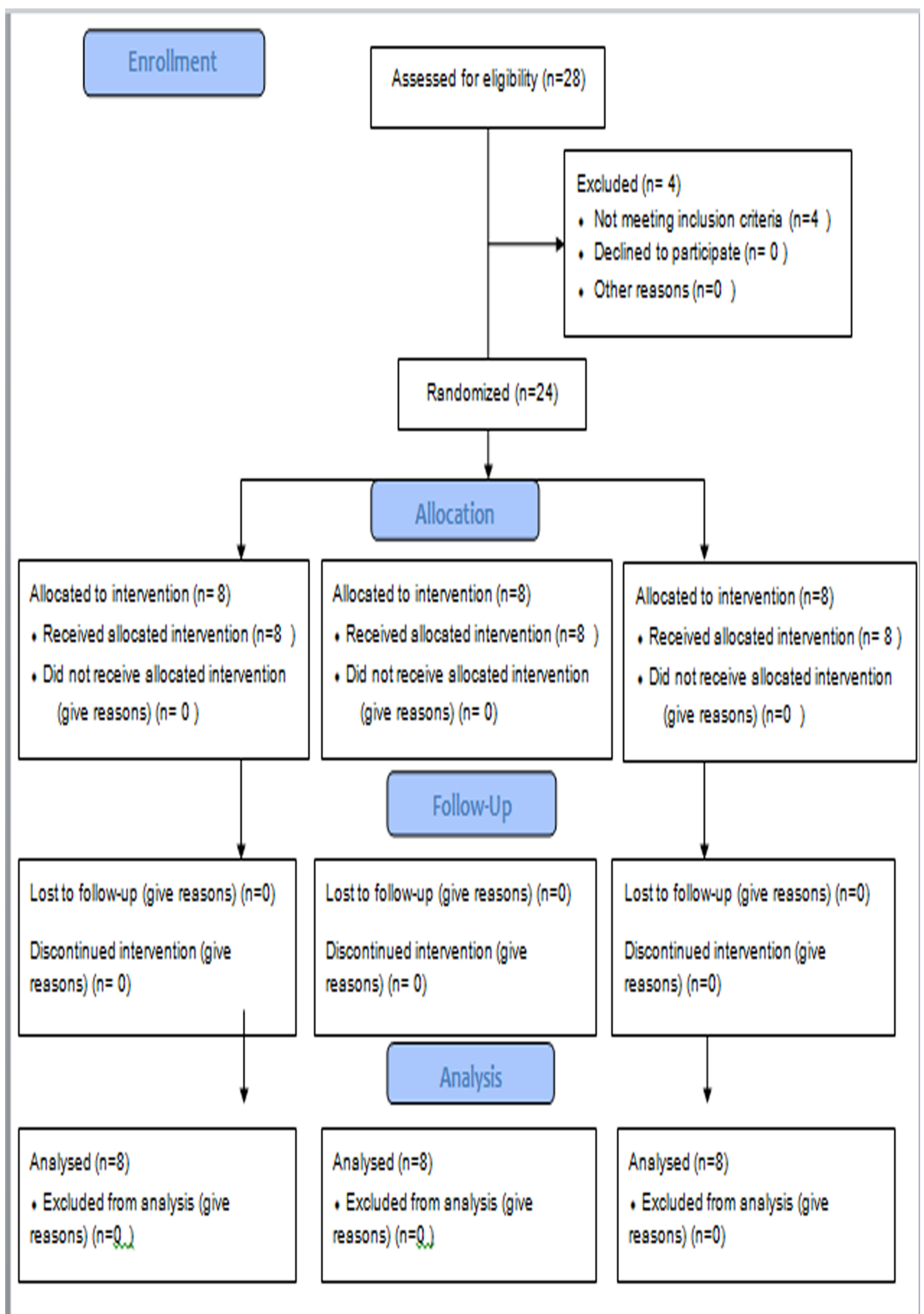

Fig. (1). The flow chart of RCT. 


\subsection{Implant Group}

Patients of this group received a fixed tooth implantsupported fixed partial denture.

\subsection{Attachment Group}

Patients of this group received a unilateral attachment removable partial denture.

\subsection{Conventional Group}

Patients of this group received a conventional skeleton removable partial denture.

Preliminary impressions were made using alginate impression (Hydrogum 5; ZhermackSpA, Italy) material in a suitable stock tray and poured in dental stone to obtain the study casts on which special trays were constructed on a $2 \mathrm{~mm}$ spacer.

\subsection{Implant Group}

A vacuum stent surgical guide was made for each patient to be used during the surgery to determine the position of implant installation; Anesthesia (Inibsa Artinibsa 4\%, Spain) was given, then the surgical guide was placed in the patient's mouth, and the probe was used to mark the proposed site for implant placement. A crystal incision was made extending 5 $\mathrm{mm}$ mesial and distal to the marked implant site. A fullthickness mucoperiosteal flap was reflected. The implant osteotomy of $10 \mathrm{~mm}$ length and $3.6 \mathrm{~mm}$ diameter was sequentially drilled, then the implant (Superline; Dentium, Korea) was installed in the osteotomy site (Fig. 2), and its cover screw was tightened, and the flap was sutured. After three months, the healing abutment was screwed to the implant and left for ten days for gingival healing and formation of the gingival collar and then replaced by the final abutment. The first and second premolar teeth in the distal extension side were reduced and prepared with sub-gingival finishing lines ready for crowing (Fig. 3). The final impression was made using a rubber base after changing the final abutment with impressiontransfer (closed tray). Composite temporary (Protemp ${ }^{\mathrm{TM}}$ Plus, USA) crowns were made, then finished, polished, and cemented temporarily.

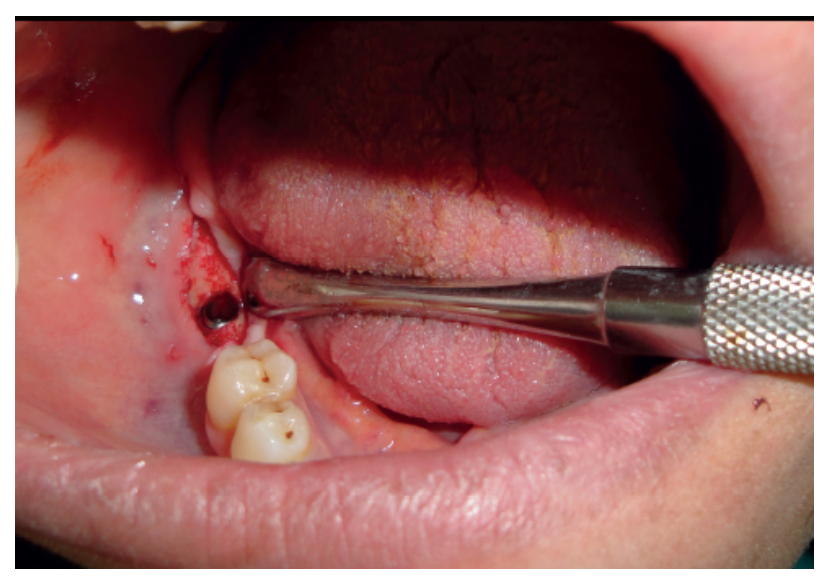

Fig. (2). The implant was installed in the osteotomy site.

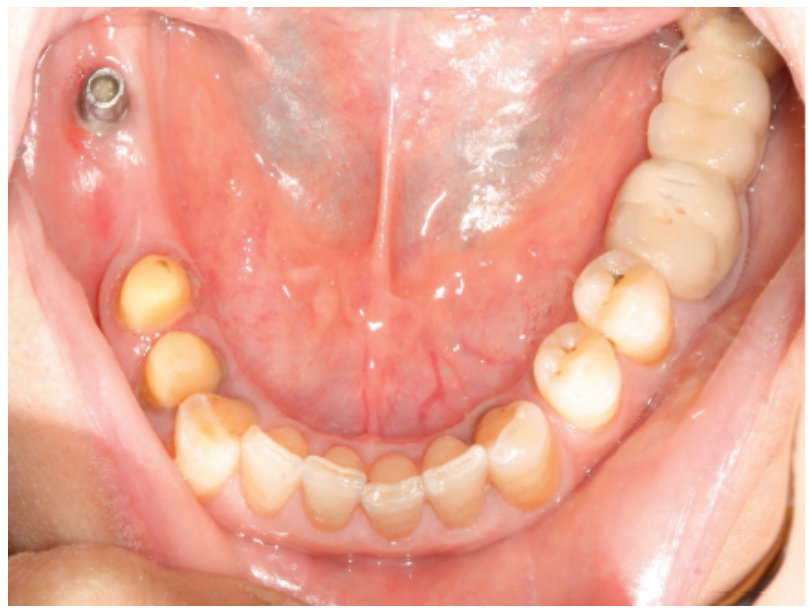

Fig. (3). Prepared first and second premolar with implant.

After obtaining the master cast with tissues mimics around the analog, sawing of the cast and dowel pin placement were carried out. A face bow record was made for mounting the upper cast on a semi-adjustable articulator. An inter-occlusal wax record was carried out for mounting the lower cast. The wax pattern for a fixed partial denture was created, invested, and cast into metal; then the metal fixed partial denture was inserted in the patient's mouth and checked for accuracy and proper seating. The porcelain shade was then selected to match the remaining natural teeth. Then the porcelain was built, the final bridge was finished and cemented with Glassionmer (Medicem Promedica Dental Material GmbH, Germany).

\subsection{Attachment Group}

The first and second premolar teeth in the distal extension side were reduced and prepared with sub-gingival finishing lines ready for crowing. In a sectional stock tray, an impression of the remaining teeth before preparation was made using putty and light rubber base (Coltenespeedx rubber base, Switzerland) for temporary crown construction. The final impression was made using putty and light rubber base. Composite temporary crowns were made and then finished, polished, and cemented temporarily.

After obtaining the master cast, sawing of the cast and dowel pin placement were carried out. A face bow record was made for mounting the upper cast on a semi-adjustable articulator. An inter-occlusal wax record was carried out for mounting the lower cast. A wax pattern for both crowns was created. The (OT unilateral) attachment (OT Unilateral, Rhein 83 , Italy) was picked up by the mandrel and connected to the surveyor to be placed and fixed carefully to the wax pattern of the distal side of the second premolar on the crest of the ridge (Fig. 4). The positioning ring was applied over the attachment, and then UNI Box was fit precisely on the attachment and flushed smoothly with the abutment wax coping. A layer of pink wax was applied on the residual ridge area of the cast before applying the saddle and then, joining the castable saddle to UNI Box by wax (Fig. 5), the completed wax pattern was sprued, invested, and cast into a metal framework and the splinted crowns attachment assembly. 


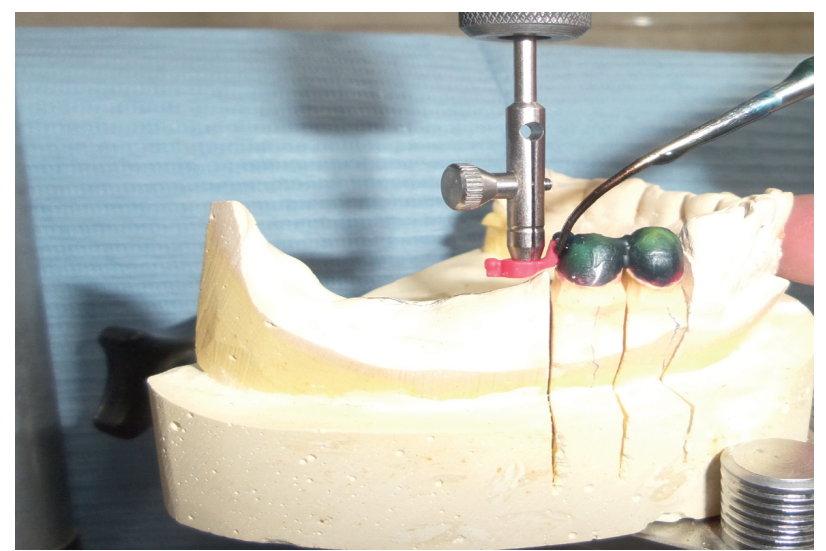

Fig. (4). The attachment fixed to the wax pattern of second premolar.

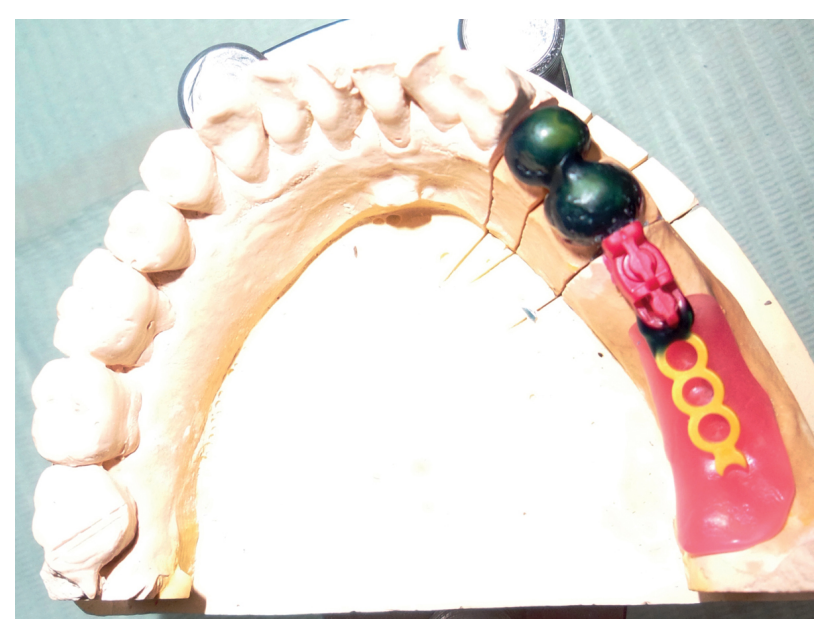

Fig. (5). The Castable saddle attached to UNI Box by wax.

The framework was inserted in the patient's mouth and checked for accuracy and proper seating of crowns. The porcelain shade was then selected to match the remaining natural teeth. Then the porcelain was built on the splinted crowns. Semi-anatomical cross-linked acrylic teeth were set up, and the try-in was carried out. The saddle base was processed into heat cure acrylic resin, and the retentive nylon caps were inserted into the frame using the caps inserting tool. The splinted crowns-attachment assembly was finally cemented using Glassionmer cement (Fig. 6); the unilateral attachment prosthesis placement was then carried out (Fig. 7).

\subsection{Conventional Group}

After surveying of the primary cast, the design of the removable partial denture included double Aker's clasp on the first and second molar of the intact side. A Reverse Aker clasp on the last abutment tooth on the edentulous side, lingual bar as a major connector, cingulum rest on canine and a meshwork extension at the free end saddle. The final impression was made for the lower arch using a medium body rubber base in a custom tray to obtain the master cast. After duplication, construction of the metal framework was done and then the metal framework was tried for accuracy and proper fit. An altered cast impression was also made. A face bow record was made for mounting the upper cast on a semi-adjustable articulator. An inter-occlusal wax record was carried out for mounting the lower cast. Semi-anatomical cross-linked acrylic teeth were set up, and try-in was carried out in the patient's mouth, and then it was processed into heat cure acrylic resin.

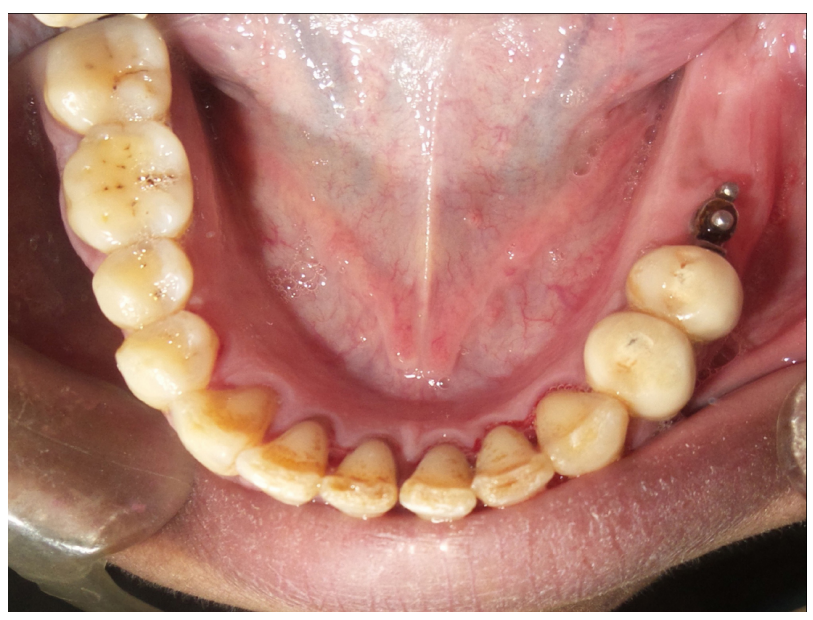

Fig. (6). Splinted crowns-attachment assembly was cemented.

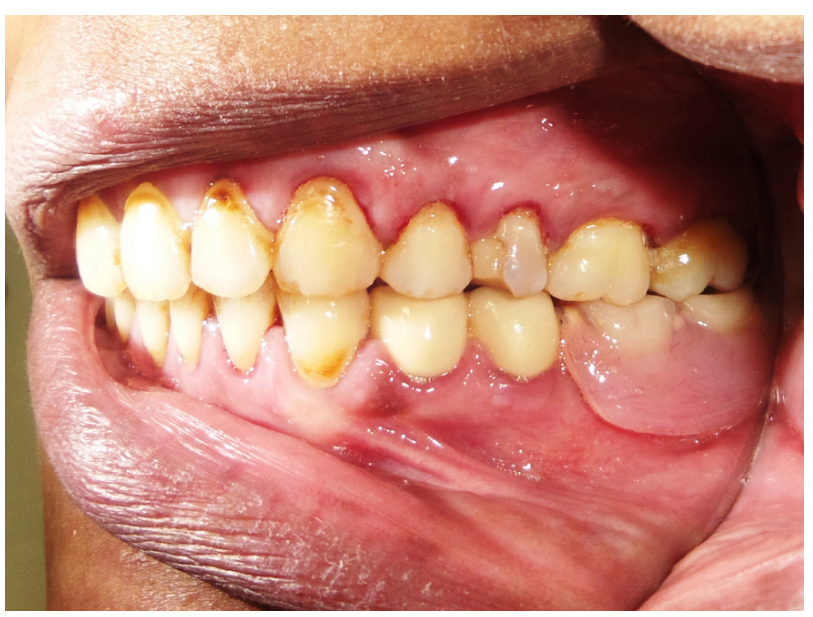

Fig. (7). Attachmentretained partial denture.

\section{EVALUATION}

\subsection{Patient Satisfaction}

The oral health impact profile-14 (OHIP14) was used, which was based on a 5-point scale ranging from 0 (never) to 4 (very often) (never, hardly never, occasionally, fairly often, and very often). Achievable OHIP-14 scores range from 0 to 56 . Lower scores represent higher patient satisfaction and better quality of life. The questionnaires were recorded at baseline (two weeks), three months, and twelve months after prosthesis insertion for patients of all groups. All questionnaires were administered by the same research interviewer (assisted interviewer); he did not know about the type of prosthesis as he was from another department. The records were done twice with an interval period of a day. All questionnaires were in English and were translated during the interview.

\subsection{Evaluation of Biting Force}

Using a load sensor (Load star sensor, 453, Ravendale 
Drive, mountain view CA 94043) device, the patient biting force was measured at baseline and after three months and twelve months. The sensor was then connected to the computer through a USB cable during the measurement procedure. The patient was seated in an upright position. The load sensor was placed horizontally between the second premolar and second molar areas. The patient was instructed to clench maximally, where the direction of applied force was vertical highest ten readings were selected from the recorded table, and the mean value was calculated.

\subsection{Radiographic Evaluation}

Digital radiographs were taken using a long-cone paralleling technique to ensure standardization of measurements at the time of prosthesis insertion (baseline), and 6,9 , and 12 months after prosthesis insertion [36].

\subsection{Statistical Analysis}

Numerical data were explored for normality by checking the distribution of data and using tests of normality (Kolmogorov-Smirnov and Shapiro-Wilk tests). Bone loss and biting force data showed normal (parametric) distribution, while OHIP-14 scores showed non-parametric distribution. Parametric data were presented as mean, standard deviation, and $95 \%$ confidence interval values, while non-parametric data were presented as median and range values. For parametric data, repeated measures ANOVA test was used to compare the groups and study the changes with time within each group. Bonferroni's post-hoc test was used for pair-wise comparisons. For non-parametric data, the Kruskal-Wallis test was used for comparison between the groups. Friedman's test was used to study the changes within each group. Dunn's test was used for pair-wise comparisons. The significance level was set at $\mathrm{p} \leq$ 0.05 . Statistical analysis was performed with IBM SPSS Statistics for Windows, Version 23.0. Armonk, NY: IBM Corp.

\section{RESULTS}

The data were collected for all participants during followup with no dropout.

\subsection{OHIP14 Result}

Both implant and attachment groups showed statistically significant lower median scores $(\mathrm{p}<.05)$ than the conventional group along with follow-up periods regarding the functional limitations, physical pain, and total score, while at insertion regarding social disability, psychological disability, and physical disability. Between implant and attachment groups, there is no statistically significant difference $(\mathrm{P}>.05)$ (Tables 1 and 2).

Table 1. Total OHIP-14 scores within each group.

\begin{tabular}{|c|c|c|c|c|c|c|c|c|c|c|c|c|c|c|c|}
\hline \multirow{2}{*}{-} & \multicolumn{5}{|c|}{ Implant } & \multicolumn{5}{|c|}{ Attachment } & \multicolumn{5}{|c|}{ Conventional } \\
\hline & Mean & SD & Median & Range & $\begin{array}{c}\text { I.Q } \\
\text { range }\end{array}$ & Mean & SD & Median & Range & $\begin{array}{c}\text { I.Q } \\
\text { range }\end{array}$ & Mean & SD & Median & Range & $\begin{array}{c}\text { I.Q } \\
\text { range }\end{array}$ \\
\hline $\begin{array}{c}\text { Functional limitation at } \\
\text { insertion }\end{array}$ & 0.25 & 0.462 & 0 & 1 & 0.5 & 0.375 & 0.74402 & 0 & 2 & 0.75 & 3.125 & 1.457 & 3 & 5 & 4.25 \\
\hline $\begin{array}{l}\text { Functional limitation } 3 \\
\text { months }\end{array}$ & 0.125 & 0.353 & 0 & 1 & 0 & 0.25 & 0.462 & 0 & 1 & 0.5 & 1.75 & 1.281 & 2 & 3 & 2.5 \\
\hline $\begin{array}{c}\text { Functional limitation } 6 \\
\text { months }\end{array}$ & 0.125 & 0.353 & 0 & 1 & 0 & 0.25 & 0.462 & 0 & 1 & 0.5 & 1 & 0.755 & 1 & 2 & 1 \\
\hline Physical pain at insertion & 0.875 & 1.125 & 0.5 & 3 & 1.5 & 1.375 & 1.772 & 1 & 4 & 3 & 3.125 & 1.125 & 3 & 3 & 2 \\
\hline Physical pain 3 months & 0.25 & 0.707 & 0 & 2 & 0 & 0.75 & 1.488 & 0 & 4 & 1 & 2.125 & 1.246 & 2 & 4 & 1.5 \\
\hline Physical pain 6 months & 0.125 & 0.353 & 0 & 1 & 0 & 0.25 & 0.462 & 0 & 1 & 0.5 & 1.25 & 1.035 & 1 & 3 & 1.5 \\
\hline $\begin{array}{c}\text { Psychological discomfort } \\
\text { at insertion }\end{array}$ & 1.375 & 1.302 & 1.5 & 3 & 2.5 & 1.625 & 1.877 & 2 & 3 & 2 & 3.625 & 1.995 & 3.5 & 5 & 3.5 \\
\hline $\begin{array}{l}\text { Psychological discomfort } \\
3 \text { months }\end{array}$ & 0.75 & 0.886 & 0.5 & 2 & 1.5 & 1.25 & 1.259 & 1 & 3 & 2 & 2 & 1.927 & 2 & 5 & 3.5 \\
\hline $\begin{array}{l}\text { Psychological discomfort } \\
6 \text { months }\end{array}$ & 0.5 & 0.755 & 0 & 2 & 1 & 0.75 & 0.886 & 0.5 & 2 & 1.5 & 1.5 & 1.414 & 1.5 & 3 & 3 \\
\hline $\begin{array}{l}\text { Physical disability at } \\
\text { insertion }\end{array}$ & 0.875 & 0.991 & 0.5 & 2 & 2 & 1.25 & 1.164 & 1.5 & 3 & 2 & 3.5 & 1.77 & 3 & 4 & 3 \\
\hline $\begin{array}{c}\text { Physical disability } 3 \\
\text { months }\end{array}$ & 0.500 & 0.744 & 0 & 2 & 0.5 & 0.625 & 0.916 & 0 & 2 & 1.5 & 1.500 & 0.834 & 2 & 2 & 1.5 \\
\hline $\begin{array}{c}\text { Physical disability } 6 \\
\text { months }\end{array}$ & 0.25 & 0.707 & 0 & 2 & 0 & 0.25 & 0.707 & 0 & 2 & 0 & 1.375 & 1.597 & 1 & 4 & 2.5 \\
\hline $\begin{array}{c}\text { Psychological disability } \\
\text { at insertion }\end{array}$ & 0.625 & 0.916 & 0 & 2 & 1.5 & 0.875 & 1.125 & 0.5 & 3 & 1.5 & 2.875 & 1.726 & 3 & 4 & 3.5 \\
\hline $\begin{array}{l}\text { Psychological disability } 3 \\
\text { months }\end{array}$ & 0.375 & 0.744 & 0 & 2 & 0.5 & 0.375 & 0.744 & 0 & 2 & 0.5 & 1.5 & 1.414 & 1 & 4 & 2 \\
\hline $\begin{array}{c}\text { Psychological disability } 6 \\
\text { months }\end{array}$ & 0.25 & 0.707 & 0 & 2 & 0 & 0.25 & 0.707 & 0 & 2 & 0 & 0.75 & 0.886 & 0.5 & 2 & 1.5 \\
\hline $\begin{array}{l}\text { social disability at } \\
\text { insertion }\end{array}$ & 0.375 & 0.517 & 0 & 1 & 1 & 0.625 & 0.744 & 0.5 & 2 & 1 & 1.5 & 1.309 & 1 & 3 & 2.5 \\
\hline
\end{tabular}


(Table $\square$ ) contd.....

\begin{tabular}{|c|c|c|c|c|c|c|c|c|c|c|c|c|c|c|c|}
\hline social disability 3 months & 0.125 & 0.353 & 0 & 1 & 0 & 0.25 & 0.707 & 0 & 2 & 0 & 0.875 & 1.365 & 0 & 3 & 2 \\
\hline social disability 6 months & 0.125 & 0.353 & 0 & 1 & 0 & 0.25 & 0.707 & 0 & 2 & 0 & 0.625 & 0.916 & 0 & 2 & 1.5 \\
\hline handicap at insertion & 0.375 & 0.744 & 0 & 2 & 0.5 & 0.375 & 0.744 & 0 & 2 & 0.5 & 0.75 & 1.035 & 0 & 2 & 2 \\
\hline handicap 3 months & 0.25 & 0.707 & 0 & 2 & 0 & 0.25 & 0.707 & 0 & 2 & 0 & 0.625 & 0.916 & 0 & 2 & 1.5 \\
\hline handicap 6 months & 0.25 & 0.462 & 0 & 1 & 0.5 & 0.25 & 0.462 & 0 & 1 & 0.5 & 0.5 & 0.755 & 0 & 2 & 1 \\
\hline Total at insertion & 4.5 & 5.345 & 2.5 & 14 & 8.5 & 7.125 & 7.472 & 6 & 20 & 11.5 & 18.125 & 10.287 & 16.5 & 27 & 17.5 \\
\hline Total 3 months & 2.125 & 2.748 & 1.5 & 8 & 3 & 3.625 & 3.420 & 3.5 & 9 & 5.5 & 10.625 & 8.584 & 10.5 & 22 & 16 \\
\hline Total 6 months & 0.5 & 0.534 & 0.5 & 1 & 1 & 1.625 & 1.846 & 1 & 4 & 3.5 & 7.375 & 7.16 & 5 & 18 & 12.5 \\
\hline
\end{tabular}

Table 2. Total OHIP-14 scores difference between groups.

\begin{tabular}{|c|c|c|c|c|c|c|c|c|c|}
\hline \multirow{2}{*}{-} & \multicolumn{3}{|c|}{ Implant-Attachment } & \multicolumn{3}{|c|}{ Implant - Conventional } & \multicolumn{3}{|c|}{ Attachment - Conventional } \\
\hline & Difference & 95\% C.I & P value & Difference & 95\% C.I & P value & Difference & 95\% C.I & P value \\
\hline Functional limitation at insertion & 0.125 & $0.5391 / 0.7891$ & 0.6925 & 2.875 & \begin{tabular}{|l|}
$1.7159 / 4.0314$ \\
\end{tabular} & $0.0001 *$ & 2.750 & $3.9905 / 1.5095$ & $0.0003 *$ \\
\hline Functional limitation 3 months & 0.125 & $0.3159 / 0.5659$ & 0.5529 & 1.625 & $0.6174 / 2.6326$ & $0.0038 *$ & 1.5 & $0.4674 / 2.5326$ & $0.0076^{*}$ \\
\hline Functional limitation 6 months & 0.125 & $0.3159 / 0.5659$ & 0.5529 & 0.875 & $0.6174 / 2.6326$ & $0.01 *$ & 0.750 & $0.0788 / 1.4212$ & $0.0311 *$ \\
\hline Physical pain at insertion & 0.5 & $2.1444 / 1.4444$ & 0.524 & 2.250 & $0.9748 / 3.5252$ & $0.002 *$ & 1.750 & $0.1056 / 3.3944$ & $0.0380^{*}$ \\
\hline Physical pain 3 months & 0.375 & $1.6242 / 0.8742$ & 0.530 & 1.875 & $0.7887 / 2.9613$ & $0.0372 *$ & 1.500 & $0.0283 / 2.9717$ & $0.0463 *$ \\
\hline Physical pain 6 months & 0.125 & $0.3159 / 0.5659$ & 0.5529 & 1.125 & $0.2958 / 1.9542$ & $0.0114 *$ & 1.00 & $0.1405 / 1.8595$ & $0.0257^{*}$ \\
\hline $\begin{array}{l}\text { Psychological discomfort at } \\
\text { insertion }\end{array}$ & 0.250 & $1.5860 / 1.0860$ & 0.6942 & 2.250 & $4.0565 / 0.4435$ & $0.0183 *$ & 2 & $0.2397 / 3.7603$ & $0.0288 *$ \\
\hline $\begin{array}{l}\text { Psychological discomfort } 3 \\
\text { months }\end{array}$ & 0.5 & 74 & 373 & 1.250 & 33 & 0.1177 & 0.750 & 55 & 0.3724 \\
\hline $\begin{array}{l}\text { Psychological discomfort } 6 \\
\text { months } \\
\end{array}$ & 0.25 & $0.6327 / 1.1327$ & 0.5533 & 1.00 & $0.2155 / 2.2155$ & 0.0994 & 0.750 & $0.5153 / 2.0153$ & 0.2243 \\
\hline Physical disability at insertion & 0.375 & $1.5342 / 0.7842$ & 0.499 & 2.625 & $4.1632 / 1.0868$ & $0.0026 *$ & 2.250 & $0.6436 / 3.8564$ & $0.0095 *$ \\
\hline Physical disability 3 months & 0.250 & $0.6449 / 1.1449$ & 0.5586 & 1.500 & $2.3475 / 0.6525$ & 0.078 & 1.250 & $2.1894 / 0.3106$ & 0.092 \\
\hline Physical disability 6 months & 0.00 & $0.7582 / 0.7582$ & 1.00 & 1.25 & \begin{tabular}{|l|}
$0.1994 / 2.4494$ \\
\end{tabular} & 0.0899 & 1.25 & $0.1994 / 2.4494$ & 0.0899 \\
\hline $\begin{array}{c}\text { Psychological disability at } \\
\text { insertion }\end{array}$ & 0.250 & $0.8501 / 1.3501$ & 0.633 & 0.250 & $0.7683 / 3.7317$ & $0.0057 *$ & 2.00 & $0.4377 / 3.5623$ & 0.158 \\
\hline Psychological disability 3 months & 0.00 & $0.7979 / 0.7979$ & 1.00 & 1.125 & $0.0866 / 2.3366$ & 0.0663 & 1.125 & $0.0866 / 2.3366$ & 0.0663 \\
\hline Psychological disability 6 months & 0.00 & $0.7582 / 0.7582$ & 1.00 & 0.500 & \begin{tabular}{|l|}
$0.3595 / 1.3595$ \\
\end{tabular} & 0.232 & 0.500 & $0.3595 / 1.3595$ & 0.232 \\
\hline social disability at insertion & 0.25 & $0.4370 / 0.9370$ & 0.448 & 1.125 & $0.0578 / 2.1922$ & $0.04 *$ & 0.875 & $0.2667 / 2.0167$ & 0.122 \\
\hline social disability 3 months & 0.125 & $0.4742 / 0.7242$ & 0.661 & 0.750 & \begin{tabular}{|l|}
$0.3191 / 1.8191$ \\
\end{tabular} & 0.154 & 0.625 & $0.5407 / 1.7907$ & 0.2694 \\
\hline social disability 6 months & 0.125 & $0.4742 / 0.7242$ & 0.661 & 0.500 & $0.2444 / 1.2444$ & 0.170 & 0.375 & $0.5024 / 1.2524$ & 0.374 \\
\hline handicap at insertion & 0.00 & $0.7979 / 0.7979$ & 1 & 0.375 & \begin{tabular}{|l|}
$0.5916 / 1.3416$ \\
\end{tabular} & 0.4193 & 0.375 & $0.5916 / 1.3416$ & 0.4193 \\
\hline handicap 3 months & 0.00 & $0.7582 / 0.7582$ & 1 & 0.375 & \begin{tabular}{|l|}
$0.5024 / 1.2524$ \\
\end{tabular} & 0.374 & 0.375 & $0.5024 / 1.2524$ & 0.374 \\
\hline handicap 6 months & 0.00 & $0.4954 / 0.4954$ & 1 & 0.250 & \begin{tabular}{|l|}
$0.4212 / 0.9212$ \\
\end{tabular} & 0.4377 & 0.250 & $0.4212 / 0.9212$ & 0.4377 \\
\hline Total at insertion & 2.625 & $4.3414 / 9.5914$ & 0.4325 & 13.625 & $22.4157 / 4.8343$ & $0.005 *$ & 11 & $20.6412 / 1.3588$ & $0.02 *$ \\
\hline Total 3 months & 1.5 & $4.8268 / 1.8268$ & 0.349 & 8.375 & $16.3525 / 0.3975$ & $0.04 *$ & 7.00 & $14.0068 / 0.0068$ & 0.052 \\
\hline Total 6 months & 0.125 & $0.3322 / 2.5822$ & 0.120 & 6.875 & $1.4305 / 12.3195$ & 0.017* & 5.750 & $0.1430 / 11.3570$ & $0.0451^{*}$ \\
\hline
\end{tabular}

\subsection{Biting Force}

The implant group showed a statistically significant $(\mathrm{p}<$. 05 ) highest mean biting force than the attachment group, which showed a statistically significant $(\mathrm{p}<.05)$ higher mean biting force than the conventional group along with all follow-up periods. Within all groups, there was a statistically significant $(p<.05)$ increase in mean biting force from baseline to 3 months as well as from 3 to 12 months (Table $\mathbf{3}$ ).

\subsection{Radiographic Evaluation}

Both the implant and attachment group showed a statistically significantly $(\mathrm{p}<.05)$ lowest mean bone loss than the conventional group along with all follow-up periods. Within all groups, there was a statistically significant $(\mathrm{p}<.05)$ increase in the mean amount of bone loss from 6 to 9 months while within the conventional group from 9 to 12 months (Table 4).

\section{DISCUSSION}

Restoration of unilateral distal extension cases can be considered a challenging task for both the prosthodontist and the patient, which is mainly due to the absence of posterior tooth support; This was overcome in this study by three different treatment modalities, which were compared regarding patient satisfaction, biting force and alveolar bone loss. 
Table 3. Comparison between biting forces in the four groups.

\begin{tabular}{|c|c|c|c|c|c|c|c|c|c|c|c|}
\hline \multirow[b]{2}{*}{-} & \multicolumn{2}{|c|}{ Natural Teeth } & \multicolumn{2}{|c|}{ Implant } & \multicolumn{3}{|c|}{ Attachment } & \multicolumn{2}{|c|}{ Conventional RPD } & \multirow[b]{2}{*}{ P-value } & \multirow{2}{*}{$\begin{array}{c}\text { Effect Size } \\
\text { (Partial Eta } \\
\text { Squared) }\end{array}$} \\
\hline & Mean (SD) & $95 \% \mathrm{CI}$ & Mean (SD) & $95 \%$ CI & $\begin{array}{l}\text { Mean } \\
\text { (SD) }\end{array}$ & $\begin{array}{c}95 \% \\
\text { CI }\end{array}$ & Mean (SD) & $95 \%$ CI & & & \\
\hline Base line & $\begin{array}{c}210.4 \\
(20.6)^{\mathrm{A}} \\
\end{array}$ & $196.1-224.7$ & $135.3(15.6)^{\mathrm{BF}}$ & $124.5-146.1$ & \multicolumn{2}{|c|}{$96.8(12.1)^{\mathrm{CF}}$} & $88.4-105.2$ & $\begin{array}{c}58.8(12.4) \\
\mathrm{DF}\end{array}$ & $48.5-69.2$ & $<0.001 *$ & 0.939 \\
\hline $3 \mathrm{~m}$ & $\begin{array}{c}212.4 \\
(21.1)^{\mathrm{A}}\end{array}$ & $197.8-227$ & $142.2(18.4)^{\mathrm{BF}}$ & $129.4-155$ & \multicolumn{2}{|c|}{$99.9(13.7)^{C F}$} & 90.4-109.4 & $\underset{\mathrm{DF}}{70.1(12.5)}$ & $59.6-80.5$ & $<0.001 *$ & 0.918 \\
\hline $12 \mathrm{~m}$ & $\begin{array}{c}210.7 \\
(20.6)^{\mathrm{A}}\end{array}$ & $196.4-225$ & $199.6(21.4)^{\mathrm{AE}}$ & $184.8-214.4$ & 140.6( & $5.1)^{\mathrm{BE}}$ & $130.1-151.1$ & $\underbrace{83.1(10.2)}_{\mathrm{CE}}$ & $74.5-91.7$ & $<0.001 *$ & 0.910 \\
\hline P-value & \multicolumn{2}{|c|}{0.547} & $<0.001 *$ & - & \multicolumn{3}{|c|}{$<0.001 *$} & \multicolumn{2}{|c|}{$<0.001 *$} & - & - \\
\hline $\begin{array}{c}\text { Effect size } \\
\text { (Partial Eta } \\
\text { Squared) }\end{array}$ & \multicolumn{2}{|c|}{0.105} & 0.771 & - & \multicolumn{3}{|c|}{0.894} & \multicolumn{2}{|c|}{0.801} & - & - \\
\hline
\end{tabular}

*: Significant at $\mathrm{P} \leq 0.05$.

A, B, C, D superscripts in the same row indicate statistically significant difference between groups.

$\mathrm{E}, \mathrm{F}$ superscripts in the same column indicate statistically significant change by time.

Table 4. Comparison between amounts of bone loss in the three groups.

\begin{tabular}{|c|c|c|c|c|c|c|c|c|}
\hline \multirow{2}{*}{ Time } & \multicolumn{2}{|c|}{ Implant } & \multicolumn{2}{|c|}{ Attachment } & \multicolumn{2}{c|}{ Conventional RPD } & \multirow{2}{*}{ P-value } & $\begin{array}{c}\text { Effect Size (Partial Eta } \\
\text { Squared) }\end{array}$ \\
\cline { 2 - 7 } & Mean (SD) & $\mathbf{9 5 \%}$ CI & Mean (SD) & $\mathbf{9 5 \%}$ CI & Mean (SD) & 95\% CI & & \multicolumn{2}{c|}{0.274} \\
\hline $6 \mathrm{~m}$ & $0.27(0.09)^{\mathrm{BE}}$ & $0.21-0.33$ & $0.30(0.09)^{\mathrm{BE}}$ & $0.24-0.36$ & $0.47(0.1)^{\mathrm{AE}}$ & $0.4-0.54$ & $0.035^{*}$ & 0.475 \\
\hline $9 \mathrm{~m}$ & $0.35(0.12)^{\mathrm{BD}}$ & $0.27-0.43$ & $0.37(0.11)^{\mathrm{BD}}$ & $0.29-0.45$ & $0.59(0.13)^{\mathrm{AD}}$ & $0.5-0.68$ & $<0.001^{*}$ & 0.482 \\
\hline $12 \mathrm{~m}$ & $0.37(0.12)^{\mathrm{BD}}$ & $0.29-0.45$ & $0.41(0.12)^{\mathrm{BD}}$ & $0.33-0.49$ & $0.65(0.1)^{\mathrm{AD}}$ & $0.58-0.72$ & $<0.001^{*}$ & - \\
\hline P-value & \multicolumn{2}{|c|}{$0.021^{*}$} & \multicolumn{2}{|c|}{$0.007^{*}$} & \multicolumn{2}{|c|}{$<0.001^{*}$} & - & - \\
\hline Effect size (Partial Eta Squared) & \multicolumn{2}{|c|}{0.332} & \multicolumn{2}{|c|}{0.398} & \multicolumn{2}{|c|}{0.924} & - & - \\
\hline
\end{tabular}

*: Significant at $\mathrm{P} \leq 0.05$.

A, B, C superscripts in the same row indicate statistically significant difference between groups.

$\mathrm{D}, \mathrm{E}, \mathrm{F}$ superscripts in the same column indicate statistically significant change by time

The result of this study supports the study hypothesis as many patients prefer the fixed restorations because it raises the patient's confidence, psychology, and ease of use; several studies reported better OHRQoL outcomes of fixed restoration rather than removable prosthesis, as mentioned in the present study [37].

Due to the nature of fixed prosthesis as well as the unique design of the OT unilateral attachment and its resiliency, the presence of two balls in different planes helped distribute the load more favorably under the masticatory forces, provided better retention without the need for cross arch stabilization and unnecessary components as well as better tolerance and adaptation of both prostheses, resulting in rapid improvement in the satisfaction scores [42].

Satisfaction scores for both implant and attachment groups were far superior as compared to the conventional group as this may be attributed to the previously mentioned advantage as well as to the fact that the masticatory load $\mathrm{n}$ both groups is mainly transmitted to the abutments, either implants or natural teeth. However, in the conventional group, the load is transmitted to both the abutment as well as the residual alveolar ridge, that is to say, tooth tissue born prosthesis with resulting sequels as trauma, inflammation, and bone resorption [10,13].

It is worth mentioning that the abutment teeth reacted favorably in all groups since the transmitted stress was within the physiological limits of supporting structures; in addition, the stress caused both biological and mechanical changes to result in both radiographic changes and muscular activity. This may explain the alveolar bone loss and increase in the biting force over time.

The statistically insignificant difference regarding alveolar bone loss between the implant and the attachment groups, along with all follow-up periods, maybe due to the splinting effect of abutments not achieved within the conventional group. Regarding all groups after 9 and 12 months follow up, no significant difference was found within all groups; however, the amount of bone loss was decreased in all groups, which may be attributed to the adaptation to stress. Therefore, it can be said that, the splinting of the abutments resulted in better load distribution and preservation of the health of the abutments [14].

The improvement of the biting force along with all followup periods may be attributed to the gradual building up experience and patient adaptation to the new prosthesis over time.

It has to be noted that the significant difference between all groups along with all follow-up periods could be explained due to the difference in the nature of the prosthesis. However, attachment showed better results both statistically and clinically, which may be due to stability, retentive clips, comfort, small prosthesis size, not crossing the contralateral side, and better neuromuscular coordination. Due to the fixed nature of the prosthesis, the absence of flanges, adaptations, and the maintenance of perioception, there were no significant 
differences between implant tooth-supported and natural teeth nearly at the end of follow-up.

\section{CONCLUSION}

The tooth implant-supported fixed prosthesis could be considered as a superior line of treatment for the management of distal extension cases.

Unilateral attachment, which is considered an excellent alternative in case of implant placement, is not recommended.

\section{ETHICS APPROVAL AND CONSENT TO PARTI- CIPATE}

This study was approved by the Research Ethics Committee of Faculty of Oral and Dental Medicine, Cairo University, Cairo, Egypt.

\section{HUMAN AND ANIMAL RIGHTS}

No animals were used in this research. All human research procedures were followed in accordance with the ethical standards of the committee responsible for human experimentation (institutional and national), and with the Helsinki Declaration of 1975, as revised in 2013.

\section{CONSENT FOR PUBLICATION}

Written and informed consent was obtained from the participants.

\section{AVAILABILITY OF DATA AND MATERIALS}

Not applicable.

\section{FUNDING}

None.

\section{CONFLICT OF INTEREST}

The authors declare no conflict of interest, financial or otherwise.

\section{ACKNOWLEDGEMENTS}

Declared none.

\section{REFERENCES}

[1] Elkerdawy MW, Radi IA. Effect of dislodging forces on mandibular implant attachment-retained overdenture. Implant Dent 2011; 20(3): 246-54.

[http://dx.doi.org/10.1097/ID.0b013e318211 fe1b] [PMID: 21613951]

[2] Büttel AE, Lüthy H, Sendi P, Marinello CP. Wear of ceramic and titanium ball attachments in subjects with an implant-retained overdenture: a controlled clinical trial. J Prosthet Dent 2012; 107(2): 109-13

[http://dx.doi.org/10.1016/S0022-3913(12)60035-3] [PMID: 22304745]

[3] Feine JS, Carlsson GE, Awad MA, et al. The McGill consensus statement on overdentures. Mandibular two-implant overdentures as first choice standard of care for edentulous patients. Gerodontology 2002; 19(1): 3-4.

[http://dx.doi.org/10.1111/j.1741-2358.2002.00003.x]

[PMID: 12164236]

[4] Nissan J, Oz-Ari B, Gross O, Ghelfan O, Chaushu G. Long-term prosthetic aftercare of direct $v s$. indirect attachment incorporation techniques to mandibular implant-supported overdenture. Clin Oral Implants Res 2011; 22(6): 627-30. [http://dx.doi.org/10.1111/j.1600-0501.2010.02026.x]

[PMID: 21070382]

[5] Yaseen A, Mohammed F, Kaddah A. Comparison of two attachments retaining mandibular immediately loaded two implant overdentures. Cairo Dental Journal 2012; 28: 1-7.

[6] Kronstrom M, Carlsson GE. An international survey among prosthodontists of the use of mandibular implant-supported dental prostheses. J Prosthodont 2019; 28(2): e622-6.

[http://dx.doi.org/10.1111/jopr.12603] [PMID: 28314082]

[7] Gosavi SS, Ghanchi M, Malik SA, Sanyal P. A survey of complete denture patients experiencing difficulties with their prostheses. J Contemp Dent Pract 2013; 14(3): 524-7.

[http://dx.doi.org/10.5005/jp-journals-10024-1355] [PMID: 24172000]

[8] Mardan N, Preoteasa C, Maria T, et al. Self-reported denture satisfaction in completely edentulous patients. Romanian. J Oral Rehabil 2013; 5: 88-95.

[9] MacEntee MI, Walton JN, Glick N. A clinical trial of patien satisfaction and prosthodontic needs with ball and bar attachments for implant-retained complete overdentures: Three-year results. J Prosthet Dent 2005; 93(1): 28-37.

[http://dx.doi.org/10.1016/j.prosdent.2004.10.013] [PMID: 15623995]

[10] Rutkunas V, Mizutani H, Takahashi H. Influence of attachment wear on retention of mandibular overdenture. J Oral Rehabil 2007; 34(1): $41-51$

[http://dx.doi.org/10.1111/j.1365-2842.2006.01640.x]

[PMID: 17207077]

[11] El-Anwar MI, El-Taftazany EA, Hamed HA, ElHay MAA. Influence of number of implants and attachment type on stress distribution in mandibular implant-retained overdentures: Finite element analysis. Open Access Maced J Med Sci 2017; 5(2): 244-9. [http://dx.doi.org/10.3889/oamjms.2017.047] [PMID: 28507636]

[12] Yang TC, Maeda Y, Gonda T, Kotecha S. Attachment systems for implant overdenture: Influence of implant inclination on retentive and lateral forces. Clin Oral Implants Res 2011; 22(11): 1315-9.

[http://dx.doi.org/10.1111/j.1600-0501.2010.02137.x] [PMID: 21426402]

[13] El-Charkawi G. Connecting implants to natural teeth. 1st International Implantology Conference. 91

[14] Brizuela A, Herrero-Climent M, Rios-Carrasco E, et al. Influence of the elastic modulus on the osseointegration of dental implants. Materials (Basel) 2019; 12(6): 980-7.

[http://dx.doi.org/10.3390/ma12060980] [PMID: 30934553]

[15] Merk S, Wagner C, Stock V, et al. Retention load values of telescopic crowns made of YTZP and CoCr with Y-TZP secondary crowns: Impact of different taper angles. Materials (Basel) 2016; 9: 354. [http://dx.doi.org/10.3390/ma9050354]

[16] Zoidis P. Polyetheretherketone overlay prosthesis over high noble ball attachments to overcome base metal sensitivity: A clinical report. J Prosthodont 2018; 27(8): 688-93.

[http://dx.doi.org/10.1111/jopr.12747] [PMID: 29322657]

[17] Zoidis P, Papathanasiou I, Polyzois G. The use of a modified polyether-ether-ketone (PEEK) as an alternative framework material for removable dental prostheses. A clinical report. J Prosthodont 2016; 25(7): 580-4.

[http://dx.doi.org/10.1111/jopr.12325] [PMID: 26216668]

[18] Hahnel S, Wieser A, Lang R, Rosentritt M. Biofilm formation on the surface of modern implant abutment materials. Clin Oral Implants Res 2015; 26(11): 1297-301.

[http://dx.doi.org/10.1111/clr.12454] [PMID: 25060652]

[19] Noiset O, Schneider YJ, Marchand-Brynaert J. Adhesion and growth of $\mathrm{CaCo} 2$ cells on surface-modified PEEK substrata. J Biomater Sci Polym Ed 2000; 11(7): 767-86.

[http://dx.doi.org/10.1163/156856200744002] [PMID: 11011772]

[20] Ohl A, Schröder K, Keller D, et al. Chemical micropatterning of polymeric cell culture substrates using low-pressure hydrogen gas discharge plasmas. J Mater Sci Mater Med 1999; 10(12): 747-54.

[http://dx.doi.org/10.1023/A:1008943625715] [PMID: 15347945]

[21] Tetelman ED, Babbush CA. A new transitional abutment for immediate aesthetics and function. Implant Dent 2008; 17(1): 51-8. [http://dx.doi.org/10.1097/ID.0b013e318167648c] [PMID: 18332758]

[22] Santing HJ, Meijer HJ, Raghoebar GM, Özcan M. Fracture strength and failure mode of maxillary implant-supported provisional single crowns: a comparison of composite resin crowns fabricated directly over PEEK abutments and solid titanium abutments. Clin Implant Dent Relat Res 2012; 14(6): 882-9.

[http://dx.doi.org/10.1111/j.1708-8208.2010.00322.x] [PMID: 21176099] 
[23] Bayer S, Komor N, Kramer A, Albrecht D, Mericske-Stern R, Enkling $\mathrm{N}$. Retention force of plastic clips on implant bars: a randomized controlled trial. Clin Oral Implants Res 2012; 23(12): 1377-84 [http://dx.doi.org/10.1111/j.1600-0501.2011.02312.x] [PMID: 22092547]

[24] Tannous F, Steiner M, Shahin R, Kern M. Retentive forces and fatigue resistance of thermoplastic resin clasps. Dent Mater 2012; 28(3): 273-8.

[http://dx.doi.org/10.1016/j.dental.2011.10.016] [PMID: 22130464]

[25] Stawarczyk B, Eichberger M, Uhrenbacher J, Wimmer T, Edelhoff D, Schmidlin PR. Three-unit reinforced polyetheretherketone composite FDPs: influence of fabrication method on load-bearing capacity and failure types. Dent Mater J 2015; 34(1): 7-12.

[http://dx.doi.org/10.4012/dmj.2013-345] [PMID: 25311236]

[26] da Fontoura Frasca LC, Castro Mattia PR, Botega DM, Rivaldo EG. Evaluation of retention forces and resistance to fatigue of attachment systems for overdentures: plastic and metal components. Implant Dent 2014; 23(4): 451-5.

[http://dx.doi.org/10.1097/ID.0000000000000093] [PMID: 25033342]

[27] Fattore L, Malone WF, Sandrik JL, Mazur B, Hart T. Clinical evaluation of the accuracy of interocclusal recording materials. J Prosthet Dent 1984; 51(2): 152-7.

[http://dx.doi.org/10.1016/0022-3913(84)90251-8] [PMID: 6366202]

[28] Engelmeier RL, Phoenix RD. The development of lingualized occlusion. J Prosthodont 2019; 28: 118-31.

[http://dx.doi.org/10.1111/jopr.12624]

[29] ELsyad MA, Maryod WH, Mostafa AZ. Effect of implant position on clinical and radiographic outcomes of locator-retained mandibular overdentures: A 1-Year prospective study. J Prosthodont 2019; 28(2): e699-704.

[http://dx.doi.org/10.1111/jopr.12780] [PMID: 29508498]

[30] Chung KH, Chung CY, Cagna DR, Cronin RJ Jr. Retention characteristics of attachment systems for implant overdentures. J
Prosthodont 2004; 13(4): 221-6.

[http://dx.doi.org/10.1111/j.1532-849X.2004.04042.x]

[PMID:

15610542

[31] Carlsson GE, Omar R. The future of complete dentures in oral rehabilitation. A critical review. J Oral Rehabil 2010; 37(2): 143-56. [http://dx.doi.org/10.1111/j.1365-2842.2009.02039.x] [PMID: 20002536]

[32] Evtimovska E, Masri R, Driscoll CF, Romberg E. The change in retentive values of locator attachments and hader clips over time. J Prosthodont 2009; 18(6): 479-83.

[http://dx.doi.org/10.1111/j.1532-849X.2009.00474.x]

[PMID: 19500236]

[33] Ettinger RL, Qian F. Longitudinal assessment of denture maintenance needs in an overdenture population. J Prosthodont 2019; 28(1): 22-9. [http://dx.doi.org/10.1111/jopr.12735] [PMID: 29380448]

[34] Alsabeeha NH, Payne AG, Swain MV. Attachment systems for mandibular two-implant overdentures: A review of in vitro investigations on retention and wear features. Int J Prosthodont 2009; 22(5): 429-40.

[PMID: 20095190]

[35] Rutkunas V, Mizutani H, Takahashi H. Evaluation of stable retentive properties of overdenture attachments. Stomatologija 2005; 7(4) 115-20.

[PMID: 16501313]

[36] Schweyen R, Beuer F, Arnold C, Hey J. Retentive characteristics of a vinylpolysiloxane overdenture attachment system. Clin Oral Investig 2015; 19(4): 947-53.

[http://dx.doi.org/10.1007/s00784-014-1307-1] [PMID: 25146180]

[37] Al-Omiri MK, Karasneh J. Relationship between oral health-related quality of life, satisfaction, and personality in patients with prosthetic rehabilitations. J Prosthodont 2010; 19(1): 2-9.

[http://dx.doi.org/10.1111/j.1532-849X.2009.00518.x]

[PMID: 19780908]

\section{C) Sharaf and Eskander}

This is an open access article distributed under the terms of the Creative Commons Attribution 4.0 International Public License (CC-BY 4.0), a copy of which is available at: https://creativecommons.org/licenses/by/4.0/legalcode. This license permits unrestricted use, distribution, and reproduction in any medium, provided the original author and source are credited. 